\title{
MOTIVATION ASPECTS IN FOREIGN LANGUAGES' ACQUISITION
}

\author{
Mārīte Opincāne \\ Rezekne Academy of Technologies, Latvia \\ Karīne Laganovska \\ Rezekne Academy of Technologies, Latvia
}

\begin{abstract}
Although foreign languages are broadly used in all spheres of life nowadays, not all students know foreign languages well. The study of students' needs in the personal realm results in a discussion of motivation, which is a very topical issue for teachers. Empirical, quantitative and information processing methods were used in the research process. The questionnaire was worked out and the data was analysed. The aim of the pilot research is to find out the students' motivation to acquire foreign languages. Several conclusions and implications were worked out. Students' attitude to the foreign languages' acquisition is positive in general. Students would like to acquire a very broad range of foreign languages, but the offer of the schools is rather limited. The role of the teacher is to encourage students' interest and motivate them to acquire foreign languages.
\end{abstract}

Keywords: motivation, language acquisition, foreign languages, questionnaire, students' attitude.

\section{Introduction}

Although foreign languages are broadly used in all spheres of life nowadays, it can often be heard and read (the results of the centralised exams in foreign languages, information from foreign students in Latvia, university students' knowledge level of foreign languages) that foreign languages' competences are not so good as it could be thought. It causes many problems, the question arises what the problems are, and therefore the authors of the paper decided to do the pilot research in the framework of the project on the motivation factors, which influence the acquisition of the foreign languages from the students' point of view. The conclusions and ideas of various researchers of the field form theoretically- methodological basis of the practical research. 


\section{Theoretical substantiation of foreign languages acquisition's motivation}

The motivation encouraging factors are essential for school students in order to learn foreign languages successfully and with interest. The authors of the research investigated the several theoretical aspects of motivation before the developing of the questionnaire and they are as follows:

- What internal and external circumstances determine it?

- Do only the aims and the needs determine motivation of foreign languages' learning?

- Can the teachers of foreign languages arise interest in other languages?

- Can the foreign language chosen also influence learning of other languages?

Bernard Spolsky considers that developed and international languages have a higher status (Spolsky, 2009, p. 106). English is the most widespread example nowadays. It is taught in most countries where it is not the first or the second language. Schools teach the literary, spoken and written standard forms of a language under the influence of different language teaching approaches, like the communicative approach.

The choice of the foreign language varies considerably all over the world. In most of the world English is now the first foreign language. B. Spolsky says that in Asia the main foreign language taught is Chinese, in the countries with Romance languages Spanish and French are emphasised and in the former Soviet Union it is still Russian. The main reasons for the choice are historical, geographical and economic. Schools are most often influenced by the availability of teachers. Richard Lambert investigated the traditional patterns in English speaking countries and found out that in Britain and Ireland students mainly study French, although Ireland is trying to expand the study of German. In the United States more and more students are studying Spanish but the acquisition of French and German is declining. Japanese is becoming very trendy. In Europe and much of the rest of the world most emphasis is put on English (Lambert, 1994, p. 54).

The European Community and the Council of Europe try to persuade member nations to teach additional languages in order to add other languages. National language diffusion agencies, for example, the British Council, the Goethe institute, the Alliance française, the Confucius institute, the Japanese foundation offer schools and universities in other countries to acquire their languages. 
B. Spolsky considers that the school environment is the final test of a theory of language management, because schools' task is basically to manage the languages of their students (Spolsky, 2009, p.114).

Motivation is an abstract notion that is not easy to define. Richard I. Arends defines motivation as "the process by which behaviour is directed toward important human goals or toward satisfying needs and motives” (Arends, 2011, p. 530). The study of students' needs in the personal realm results in a discussion of motivation, which is a very topical issue for teachers. It is internal to everybody. However, experienced teachers know that it is one of the essential forces that guides students' actions. R.I. Arends considers that three most essential ideas guide modern thinking on motivation and each of them can be restated into practical strategies for teachers to think about: Need Disposition Theory, Attribution Theory and Flow. Need Disposition Theory displays the point of view, which learners are motivated to participate in and fill energy in achieving of three outcomes: achievement affiliation and influence. Achievement motives expose themselves in teachers as they strive to ensure good instruction and perform as qualified professionals. Affiliative motives become essential when students and teachers understand the worth of their peers' support and friendship. The motivation toward influence can be observed in the students who devote serious efforts for their learning and in the teachers who wish to contribute into schools' management and administration. Achievement motivation is the most essential in this theory. Attribution theory is an alternative explanation of achievement motivation. It is based on assumption that the way the learners perceive and explain the reasons of their achievements and failures of their success motivation. Teachers can contribute a lot and it can result in increase of students' effort. Flow experiences are based on the states of optimal experiences - involvement, concentration and positive feelings of enjoyment. It stresses the importance of developing challenging and enjoyable learning experience (Arends, 2011, p. 114 - 116).

Robert Gardner and Wallace Lambert were the first researchers who showed statistically essential and favourable relations between motivation, positive attitudes to the second language and its speakers and mastery of the second language aspects that are less subjected to conscious manipulation (Gardner \& Lambert, 1959, p. 266 - 272). John Carroll (1962) demonstrated that, after aptitudes, attitudes were the second most essential of variables for foreseeing the second language learning achievements. By time passing, language attitudes appeared to be one of the key affective variables, which explained the second language mastering outcomes via their links to motivation. R. Gardner considers that motivation is "the combination of desire and effort to achieve a particular goal, which linked individuals' rationales for particular 
activities with the range of behaviours and degree of effort employed in achieving their goals" (Gardner, 1985).

R. Gardner and W. Lambert pointed out the difference between two types of attitudes and resulting motivation: integrative when the learners are motivated by their eagerness to identify with the second language group and instrumental when the learner is motivated to learn the second language for practical purposes. The authors concluded that the integrative attitudes or combination of both attitudes predominantly will result in the higher achievements (Gardner \& Lambert, 1972). By time passing, several models of the second language acquisition integrated attitudes as an essential efficient factor that can explain the differences in the second language outcomes. The Monitor Model is the most popular among them. It is the first comprehensive theory of the second language acquisition. It consists of five components and one of them is the Affective Filter, which contains such factors as attitude, motivation and anxiety. The hypothesis of the Affective Filter formulates that efficient factors do not influence language mastering directly but that they either promote or deter input from achieving the language-mastering tool (Krashen, 1994). Learners who have a positive attitude and low anxiety will have a "low" filter and therefore reach a high language command but those who have a negative attitude and a high anxiety will have a "high filter" and it will cause difficulty for the input and the second language learning (Pavlenko, 2005, p. 32). Aneta Pavlenko discusses attitudes and motivation as dynamic phenomena. (ibid.)

\section{Methodology}

The authors of the paper participate in the implementation of the European Social Fund (ESF) co-funded project: 'Strengthening the academic staff of Rezekne Academy of Technologies in the study field "Education, pedagogy and sports". The aim of the project is to strengthen the academic staff of Rezekne Academy of Technologies in the study field "Education, pedagogy and sports" by developing professional competence of RAT academic staff. The RAT academic staff have an internship at different secondary schools in Latvia and they will use knowledge and experience acquired in the perfection of their courses.

The aim of the pilot research: to find out the students' motivation to acquire foreign languages. 102 students were surveyed. Their age range was from 13 through 19. The questionnaire was carried out at Baltinava Secondary School (BSS) where students acquire the English and Russian languages as foreign languages and at Rezekne State First Grammar School (RSFGS) where the students master the English and German or Russian languages. The foreign languages, which have been mastered are the English language as the first 
foreign language, the German language or the Russian languages as the second foreign language.

Empirical, quantitative and information processing methods were used in the research process. The questionnaire was worked out and the data was analysed.

\section{Results and Discussion}

The choice of the foreign languages has been determined by the school offer, which in its turn results from the number of the lessons allocated for the foreign languages, the professionals available at school and the number of the students in the group - if it justifies financially the costs of the foreign language's acquisition in a small group. However, the data of the questionnaire prove that the students' interest in foreign languages' acquisition is much broader, which states that a modest offer of the schools and a limited financing do not correspond to the steadily increasing requirements of the age. Except the languages offered, the students would like to acquire Estonian, Polish, Lithuanian, Bulgarian, Latin, Danish, French, Portuguese, Finnish, Swedish, Norwegian, Korean and Chinese. And the Spanish language is at the top of the languages' rating, which the students would like to acquire.

One of the motivating factors to acquire as many foreign languages as possible is an opportunity to travel. The mobility of the $21^{\text {st }}$ century offers to almost anyone who wants it, opportunities to visit both near and far-off countries. It has been proved also by the results of the questionnaire: $84 \%$ of the students surveyed have been abroad. The most visited countries, of course, are the neighbour countries (Lithuania, Estonia, Russia, Belarus), but most students have also been in Poland, Sweden. Germany, Great Britain, France, the Czech Republic, Switzerland and others. The number of the countries visited is varied and broad that points out that there is not only an opportunity but also a desire to become acquainted with other countries.

Answering the question what encourages to visit foreign countries, the dominating answer is a desire to get acquainted with the culture of other countries and to see famous sightseeing objects, more rarely - visiting of the relatives and seeing nature. It has been noted in the answers that the knowledge of the foreign languages (Russian and English) determines the choice as opportunity to communicate and correspondingly the feeling of safety in a strange/unknown country, in its turn, results from it. The question on the communication language abroad has been answered mentioning English as the dominating language, then the Russian the German languages follow. 
The main module of the questions in the questionnaire is related to students' attitude to the learning of foreign languages. The majority of the students surveyed (78.6\% (BSS), 79.7\% (RSFGS)) attests that they like foreign languages. Students' general attitude to the acquiring of the foreign languages has been reflected in the table below and it can be concluded that it is positive in general, and possibly it is determined by the fact that the process of foreign languages' acquisition at these schools is well-considered, interesting and implemented at a high level (see Table 1).

Table 1 Students' attitude to acquisition of foreign languages

\begin{tabular}{|l|c|c|}
\hline \multicolumn{1}{|c|}{ Statement of questionnaire } & $\begin{array}{c}\text { Total number of answers } \\
\text { at BSS } \\
\text { (total number of the } \\
\text { students surveyed - 28) }\end{array}$ & $\begin{array}{c}\text { Total number of } \\
\text { answers at RSFGS } \\
\text { (total number of the } \\
\text { students surveyed - 74) }\end{array}$ \\
\hline $\begin{array}{l}\text { I like foreign languages and I am } \\
\text { interested in them. }\end{array}$ & 22 & 64 \\
\hline $\begin{array}{l}\text { I learn in independently, outside school } \\
\text { assignments. }\end{array}$ & 14 & 44 \\
\hline I don't study anything additionally. \\
\hline $\begin{array}{l}\text { Acquisition of foreign languages is not } \\
\text { necessary. }\end{array}$ & 12 & 21 \\
\hline I am keen on learning foreign languages. & 1 & 27 \\
\hline $\begin{array}{l}\text { Learning of foreign languages does not } \\
\text { cause any difficulties. }\end{array}$ & 14 & 22 \\
\hline $\begin{array}{l}\text { Acquisition of foreign languages does not } \\
\text { come easy for me as it is complicated. }\end{array}$ & 11 & 17 \\
\hline $\begin{array}{l}\text { Acquisition of foreign languages is } \\
\text { boring. }\end{array}$ & 5 & 11 \\
\hline $\begin{array}{l}\text { Learning of foreign languages leaves me } \\
\text { indifferent. }\end{array}$ & 2 & 50 \\
\hline
\end{tabular}

The results, which bring about contemplation were acquired in the group of the question "Mastering of foreign languages/knowledge and the future plans." 96 out of 102 students surveyed consider that knowledge of foreign languages could influence the development of their career. 26 BSS students and 66 RSFGS students recognize that they will need foreign languages after graduating of school. However, 2 BSS students and 5 RSFGS students are not sure about it. The students from both schools surveyed consider English and Russian as the prior languages for their future: 2 BSS students and 11 RSFGS students have also named German, 1 RSFGS student - Spanish. In the questionnaire, students also revealed the motives why they would need foreign languages (see Table 2). 
Table 2 The internal motivating factors of foreign languages' acquisition

\begin{tabular}{|l|c|c|}
\hline \multicolumn{1}{|c|}{ Statement of questionnaire } & $\begin{array}{c}\text { Total number of } \\
\text { answers at BSS (total } \\
\text { number of the students } \\
\text { surveyed - 28) }\end{array}$ & $\begin{array}{c}\text { Total number of } \\
\text { answers at RSFGS (total } \\
\text { number of the students } \\
\text { surveyed - 74) }\end{array}$ \\
\hline $\begin{array}{l}\text { It is the tendency of the epoch } \\
\text { everyone has to know foreign languages. }\end{array}$ & 25 & 66 \\
\hline $\begin{array}{l}\text { Desire to travel, to get acquainted with } \\
\text { other nation, cultures. }\end{array}$ & 28 & 70 \\
\hline $\begin{array}{l}\text { The plans and intention are linked with } \\
\text { studies, learning abroad. }\end{array}$ & 6 & 44 \\
\hline $\begin{array}{l}\text { The plans are concerned with work } \\
\text { abroad. }\end{array}$ & 13 & 7 \\
\hline $\begin{array}{l}\text { Foreign languages will not be necessary } \\
\text { in the profession. }\end{array}$ & 3 & 44 \\
\hline
\end{tabular}

The authors of the research propose the following ideas as the methodological discussion of foreign languages' acquisition:

- Students' attitude to the foreign languages' acquisition is positive. They see different opportunities to apply this knowledge in the future - during travelling, studying and work. It means that an opportunity to apply the competence of foreign languages encourage their acquisition. It would help to influence positively the fact that the acquisition of foreign languages causes difficulties, is boring or leaves students bored, makes to draw conclusion that these factors influence motivation and decreases desire and enthusiasm to master foreign languages.

- In the process of foreign languages' acquisition a teacher has to correlate the put forward aim and the content according to the profile of the students' group (skills, abilities, knowledge), as well as to get feedback A low self- esteem and weak results irreversibly destroy student's motivation to learn a particular foreign language. As foreign colleagues precisely point out: "Positive feedback not only from teachers, but also from other learners, different methods of selfassessment of learners, avoidance of social comparisons and promotion of individual reference standards, avoidance of competitive tasks are important aspects of feedback and assessment." (Karagiannakis \& Taxis, 2017, 8)

- Students would like to acquire a very broad range of foreign languages, but the offer of the schools is rather limited, it is determined by different circumstances. However, the opportunities to offer other learning forms and potentialities have to be found via 
positive influencing on students' desire to learn. Students have various different opportunities to use different digital tools (for example, duolingo.com, busuu.com, memrise.com etc.) and other opportunities (for example, there is an opportunity to learn Chinese at Rezekne Academy of Technologies).

- Individual acquisition of a foreign language (also via digital instruments) is valuable and efficient when a student is highly motivated. As a language and socialisation are closely linked, foreign languages' teachers are advised to leave an individual work for home assignments but during the classes to practice cooperative learning more. It shows the following interfaces between motivation and the principles of cooperative learning: social inclusion, feedback, competence experience, autonomy of the learners. (Thelen, 2017, 31) It is an opportunity for students via teamwork to apply their foreign languages' knowledge in practice, learn from others, but the main task was to do the task with responsibility as its result is a part of the group's common work.

- Textbooks and other teaching materials and aids not always keep students' attention and are topical and up-to-date. Teachers should constantly think how to update topics, instruments and programmes (for example, kahoot.it, quizizz.com, google apps etc.) and make them more modern.

- Teachers should use positive examples and stories more, which are linked with foreign languages' role in the development of career, for example the skype meeting with someone who knows foreign languages well and it has helped him/her in the development of the career.

- $\quad$ The role of the teacher is not only to popularize their topic but also to encourage students' interest and motivate them to acquire other foreign languages.

\section{Conclusions}

The authors have managed to outline the basic essence of motivation as the result of the pilot research: motivation is complex and varying, as it consists of several mutually linked components and it is individual for every student, although external influencing factors can be identical or similar. As the authors of the paper noted before, it is a pilot research, and it revealed the current tendencies in motivation of foreign languages' acquisition and let propose the issues for discussion. It is a good start for a broader research. It is the first stage 
of the pilot research as both schools are located in the same region. The research can be developed by a comparative research via a broader regional view. The teachers of foreign languages with their opinions and vision on the factors, which influence students' motivation to acquire foreign languages and teacher's role in this process could be involved in the research.

\section{References}

Arends, R.I. (2011). Learning to Teach. New York: McGraw -Hill.

Carroll, J. (1962). The prediction of success in intensive foreign language training in R. Glazer (Ed.) Taining, Resarch and Education. Pittsburgh: University of Pittsburgh Press.

ESF projekti: Rēzeknes Tehnolog̣iju akadēmijas akadēmiskā personāla stiprināšana studiju virzienā "Izglìtība, pedagoǵija un sports" 8.2.2.0/18/I/002 Retrieved from https://www.rta.lv/esf_lidzfinansetie_projekti?project_id=113

Gardner, R. (1985). Social Psychology and Second Language Learning: The Role of Attitude and Motivation. London: Edward Arnold

Gardner, R., \& Lambert, W. (1959). Motivational variables in second language acquisition. Canadian Journal of Psychology, 13 , 266 - 272 .

Gardner, R., \& Lambert, W. (1972). Attitudes and Motivation in Second Language Learning.

Karagiannakis, E., \& Taxis, S. (2017). Motivation im Deutschunterricht. Fremdsprache Deutsch, 57, 3 - 9 .

Krashen, S. (1994). The input hypothesis and its rivals. In N. Ellis (Ed.), Implicit and Explicit Learning of Languages. New York: Academic Press.

Lambert, R. (1994). Problems and processes in US foreign language planning. Annals of the American Academy of Political and Social Sciences, 532, 47 - 58.

Pavlenko, A. (1995). Emotions and Multilingualism. Cambridge: Cambridge University Press. Spolsky, B. (2009). Language Management. Cambridge: Cambridge University Press.

Thelen, von J. (2017). Motivation von lernenden durch kooperative Unterrichtsformen. Fremdsprache Deutsch, 57, 30 - 34. 